\title{
EMPLOYEE ENGAGEMENT \& RETENTION: A REVIEW OF LITERATURE
}

\author{
Munish ${ }^{1}$, Rachna Agarwal ${ }^{2}$ \\ ${ }^{1}$ Assistant Professor, Aravali College of Engineering \& Management, Faridabad, India \\ ${ }^{2}$ Associate professor, YMCA University of Science and Technology, Faridabad, India
}

\begin{abstract}
The other objective is to analyze the critical factor which can affect the level of retention \& engagement of employees with the help of literature review. For the current article the researchers reviewed 30 relevant research papers/ literature comprising employee retention\& engagement concepts and practices amply. The findings of the study like good training \& development, compensation structures, autonomy, quality of work life, work polices and arrangements will lead the managers and management to a new dimension with holistic approach in the field of employee retention \& engagement.
\end{abstract}

\section{KEYWORDS}

Employee Retention, Information Technology Sector, HR Practices, Employee Engagement

\section{INTRODUCTION}

A study stated in his study that one of the most critical challenges now a days international firms are facing is attrition of good employees. The research study concluded that employee engagement threw leadership becomes a critical tool to face the competition and enhance the chance of the growth and serve an indicator of the good will of the firm ${ }^{[1]}$. A study concluded extracted that HRM practices like effective leadership, communication, value profiles must be integrate with strategic goal that can drives good financial condition of employee which leads to retention of employees ${ }^{[2]}$. Renowned article, "Strategies for survival in the war of talent" that was result from a survey in of 330 companies with in 50 countries the concluded that employee leaves the job because the boss is not supportive and biasness from boss in lying there ${ }^{[3]}$. The result of research in way that the leader and their leadership styles variations influence their personal status and their work experiences. That led them to leave the organizations ${ }^{[4]}$.

\section{LITERATURE REVIEW}

Various studies has been done in the area of employee retention and engagement worldwide. Some of the studies has been studied in the current study and explained their conclusion as below. 
International Journal of BRIC Business Research (IJBBR) Volume 6, Number 1, February 2017

\subsection{EMPLOYEE ENGAGEMENT}

A Study explores employee engagement as a motivating, dedicating feeling to accomplish a task efficiently ${ }^{[5]}$. The authorsexamine the Kahn's model and the findings of that model supported that the good working conditions, safety measures, time of work and positivity in the organization is directly linked with employee engagement ${ }^{[6]}$. A Study define engagement as the extension of commitment ${ }^{[7]}$. A research elaborated employee engagement more extensively and divide engagement in to two areas one is engagement with job and other is engagement with the organization $^{[8]}$. The study describes employee engagement as" long lasting, positively and motivational approach of employees that results in high level of work involvement with passion and dedication ${ }^{[9]}$. A study define Employee Engagement as individual cognitive state and his positive behavior and emotions that lead him to work in tandem with organization goals ${ }^{[10]}$.

\subsection{DRIVERS OF EMPLOYEE ENGAGEMENT}

A study stated that a study on factors of employee engagement in food industry in Jordan hotel industry the key point reveled after analysis the development opportunities, communication channels, rewards recognition \& growth, employer's concern \& care in industry have a great impact on employee engagement ${ }^{[11]}$. A research analyzed that relationships among peers \& subordinates and team partners, employees status, development options, job description, support from managers, trust \& loyalty has positively related to employee engagement ${ }^{[12]}$. A study concluded their study that the level of employee engagement is affected by varous factors like autonomy, clarity in roles, and unity of direction has significant relationship with employee engagement $^{[13]}$. A study done in hotel industry in Bali analyzed job specification \& support from top managers has highly correlated with employee engagement ${ }^{[14]}$. A research concluded that challenging roles, nature of work, and quality of work life, communication, and appraisal leads to high level of employee engagement ${ }^{[15]}$. In a study done the results reveled that resources for job, description and job specification have the strong relationship which decide the level of engagement and retention of employees ${ }^{[16]}$. A result of the study stated that good human resource practices will lead to enhance the level of engagement ${ }^{[17]}$. A study stated in a study conducted an internet survey from IT sector \& Banking sector. They had revealed that job specifications, key role, challenging nature of work, equity, climate of work are closely linked with employee engagement ${ }^{[18]}$. In a study done with convenience sampling of 310 samples studied that support from immediate boss, equity level in office, non-monetary rewards are significantly related to employee engagement ${ }^{[19]}$. With the analysis of detailed literature stated that level of motivation, work involvement, support from organization, performance appraisal, quality of work life have positively linked with behavior of employees and their engagement ${ }^{[20]}$. A study revealed that culture of organization, communication, integrity of goals, autonomy are the significant predictors of employee engagement ${ }^{[21]}$. A study stated that communication ease and personality traits are the factors which decide the level of retention ${ }^{[22]}$. A research states in a study that policy of recruitment \& selection, job description, development opportunities, styles of leadership, empowerment, performance appraisals, salary structures, work life balance, health \& safety arrangement are highly correlated with level of employee engagement ${ }^{[23]}$. In a study conducted on 279 employee of restaurant in Southern Norway examined the autonomy in job, decision making freedom, role clarity, training \& development opportunities are highly correlated with level of engagement ${ }^{[24]}$. A research concluded that support from co-workers, nature of job, employee's participation in management are highly correlated with employee engagement ${ }^{[25]}$. A survey 
concluded that leadership styles, behavior of supervisor \& trust and loyalty has a great impact on employee engagement ${ }^{[26]}$. A study Conclude that level of employee engagement in highly influenced by the nature of job, communication ease, leadership styles, and trust level and job autonomy ${ }^{[27]}$. A research analyzed that forces for employee engagement are leadership styles, team work, nature of work, support form supervisor, empowerment, quality of work life, monetary and non-monetary rewards have significantly related with engagement. The drivers of engagement are opportunity to grow, effective communication, training \& development facility, work design are some crucial factors which are highly correlated with engagement of employees ${ }^{[28]}$. The authors concluded that growth opportunities, quality of work life, working conditions, role clarity have significantly associated with level of employee job engagement ${ }^{[29]}$. Authors in research conducted suggested that level of job satisfaction, level of involvement in decision making, opportunity to grow are the strongest drivers of employee's engagement ${ }^{\left[{ }^{[0]}\right.}$.A study results extracted a positive relationship between job description, performance appraisal, support from supervisor and employee engagement is highly correlated ${ }^{[31]}$. The results of a study stated leadership quality has an impact of engagement. They stated that health benefits, empowerment, training \& development, salary structure, equity, communication, empowerment, recreational activities are strongly related to employee engagement ${ }^{[32]}$.

\subsection{EMPLOYEE RETENTION}

A study concluded that for retaining good talented work force the organization has to create a positive environment for conducive working ${ }^{[33]}$. A study analyzed that good and successful organizations do respect their employees and try to make policies more flexible for betterment of employees so that level of employee engagement can be achieved ${ }^{[34]}$. The result of a study showed that retention is the process in which employer takes steps to prevent the job switching of their key employees ${ }^{[35]}$. A studydescribe that retention is an effort by which an employer make some good policies to retain talented employees for achieve the organization goals and success ${ }^{[36]}$. A study concluded that talented work force has high worth to the organizations due their expertise over the knowledge, their skills \& experience ${ }^{[37]}$. A study stated that organization treats them as an assets. Most of the previous studies agreed upon that good retention strategies leads to greater time span in the organization and also motivates them to do their job dedicatedly ${ }^{[38]}$.

\subsection{FACTORS AFFECTING EMPLOYEe RETENTION}

A study postulated thatthe HR professional needs to point out the critical points why employees leaves the organization so that proper prevention measure can be exercised. If an organization fails to cope up the retention issue on time it become huge problem so some retention practice can be adopted ${ }^{[39]}$.

\subsection{Training \& DeVElopMent}

A study stated that good Training and development exercises can high up the rate of retention because by the training they achieve their as well organizational goal in time and will be benefited to rewards ${ }^{[40]}$. A study concluded that good knowledge based organization now emphasizing on training \& development activities. Previous HR studies also states that these will induce retention ${ }^{[41]}$. A study showed that high growth of an organization is depend on ability of employees. To achieve the level of competitive advantage the comprehensive training \& development programmes must be applied ${ }^{[42]}$. A research concluded that good training programmes lead to high rate of employee retention ${ }^{[43]}$. 
International Journal of BRIC Business Research (IJBBR) Volume 6, Number 1, February 2017

\subsection{COMPENSATION}

The research conducted on employee retention stated that financial perks is the major factor on which the relationship between the employee and intention to stay in organization can be measured ${ }^{[44]}$. A study on employee engagement concluded that a competitive pay structure is a vital aspect that easily affect the level of retention ${ }^{[45]}$. The research concluded that good administrated Compensation structure plays a vital role in retaining the employees. So therefore it is required to reforms the existing pay structures as per need and trend of the market ${ }^{[46]}$.

\subsection{Organizational Culture}

The authors of a studyanalyzed the term organizational culture in detail. It may a set of rules, the values, an organization possess the leading behaviors affected by business environment Culture plays an important role in retaining the employees if strong and positive culture is lying there the rate of retention also hoes high ${ }^{[47]}$. A research conducted on retention of employees stated that culture cannot be static rather it's dynamic which should be reframed and reformed as per the business environment. New ideas, new theories and new believes can be implemented. The organizational culture is vital factor to retain employee so the organization always strive for the betterment of the working culture. New policies and practices can be implemented there ${ }^{[48]}$.

\subsection{LEADERSHIP}

A study on employee retention and engagement stated that good Leaders plays very key role in the success of an organization because their quality motivated and induce the sub-ordinate to do well. And retain for longer periods of time. For example, Leaders and subordinates are so much correlated with each other to discuss their level of engagement ${ }^{[49]}$. A study (stated that those leaders who supports the behavior of subordinated in task delegation and performing the activities will lead to positive engagement with them. Transforming leaders with a great vision about their followers generally creates history in the field of subordinate retention ${ }^{[50]}$. A research conducted on employee retention stated that perception of managers regarding the level of retention of employees if he thinks about the followers with equity this will motivate subordinates to do well for the organization and on the same time felt good for them as well ${ }^{[51]}$. A study conducted on retention of employees explored that leadership styles has a great impact on level of retention because it directly affects the cognitive state of employees. This approach drives the level of consequences up to minimum ${ }^{[52]}$.

\subsection{FEEDBACK}

A research conducted on employee retentionconclude that economic, Social and mental condition of an employee is strongly affected by positive feedback within the organization ${ }^{[53]}$. A study done on employee retention positive feedback from supervisor and co-workers are highly correlated with level of retentionconcluded that feedback is the benchmark that motivates and drives the employee productivity level and on the same time their retention level ${ }^{[54]}$. A study concluded on engagement of employees stated that feedback also at times went negative and hugely affect the retention of employees and also explored some aspect of feedback that includes the trust, harmony, individual differences, comparisons, communication style all these factor influence the retention of employees ${ }^{[55]}$. 
International Journal of BRIC Business Research (IJBBR) Volume 6, Number 1, February 2017

\section{OBJECTIVES}

The current study has two objectives:

a. To identify the meaning of retention and engagement of employees in the organization as well as its significance.

b. To analyze the factors which can affect the level of retention \& engagement of employees with the help of literature review.

\section{Methodology}

This current study analyzed the previous studies took place in past on employee engagement \& retention for summarizing it and establish a distinctive phenomenon. This study serves as a guide, for searching and choosing relevant literature was considered as the first step. The following is an outline of the literature selection process, specifying (a) Source of articles were found, (b) Time of study, (c) who processed the search, (d) how the literature were extracted, (e) final no of articles selected, and (f) Reason for selected papers .

This present study used 30 research papers (e.g., Google scholar, Emerald, Springer, Elsevier, ProQuest Education Journals, Taylor \& Francis, Scopus Psyc INFO, and Psyc ARTICLES) to find out relevant data for the study. The researcher tried to extract as many relevant articles as possible. The research conducted in July, 2016 from above mentioned scope. To have the clear picture of the topic this study include the peer-reviewed research papers published in English. The review of literature method in current study it is a relevant research approach for defining and synthesizing the extant body of literature related to a certain phenomenon.

\section{ANALYSIS OF Literature}

In total 30 research papers were analyzed. A summary of the literature appears in Table 1 shows the literature summary in chronological order. The summary concludes authors name, purpose/objectives, sample data information, and key findings/ conclusion from the articles.

Table 1. Analysis of Research Articles

\begin{tabular}{|c|c|c|c|c|}
\hline Authors & Objective/Purpose & Sample Size & $\begin{array}{l}\text { Constructs/Variables } \\
\text { Studied }\end{array}$ & Key Findings \\
\hline $\begin{array}{l}\text { Saket } \\
\text { Jeswani and } \\
\text { Souren } \\
\text { Sarkar }{ }^{[56]} \\
\text { (2008) }\end{array}$ & $\begin{array}{l}\text { To Examine the } \\
\text { effect of engagement } \\
\text { on Individual } \\
\text { outcomes such as job } \\
\text { effectiveness and } \\
\text { retention. }\end{array}$ & $\begin{array}{l}\text { The sample size of } \\
\text { this study was } 150 . \\
\text { (North Carolina, } \\
\text { USA.) }\end{array}$ & $\begin{array}{l}\text {-Feeling valued } \\
\text {-Career } \\
\text { Development } \\
\text {-Two Way } \\
\text { Communication } \\
\text {-Good Quality Line } \\
\text { Management }\end{array}$ & $\begin{array}{l}\text { To result conclude } \\
\text { if talent } \\
\text { engagement is not } \\
\text { evaluated and } \\
\text { handled as soon as } \\
\text { possible } \\
\text { disengaged talents } \\
\text { will multiply and } \\
\text { negative talent } \\
\text { satisfaction issues } \\
\text { can result in: } \\
\text { Decreased } \\
\text { Motivation. }\end{array}$ \\
\hline
\end{tabular}


International Journal of BRIC Business Research (IJBBR) Volume 6, Number 1, February 2017

\begin{tabular}{|c|c|c|c|c|}
\hline $\begin{array}{l}\text { Ologbo C. } \\
\text { Andrewa, } \\
\text { Saudah } \\
\text { Sofianb }{ }^{[57]} \\
\text { (2012) }\end{array}$ & $\begin{array}{l}\text { The main aim is } \\
\text { ascertaining the } \\
\text { uncertainty about the } \\
\text { influence of } \\
\text { individual factors of } \\
\text { employee } \\
\text { engagement on work } \\
\text { outcomes using the } \\
\text { measures } \\
\text { employee } \\
\text { engagement. }\end{array}$ & $\begin{array}{l}\text { The participants of } \\
\text { this study were } 104 \\
\text { HR officers at the } \\
\text { Inland Revenue } \\
\text { Board of Malaysia. }\end{array}$ & $\begin{array}{l}\text {-Employee } \\
\text { Communication } \\
\text {-Employee } \\
\text { Development } \\
\text {-Organization } \\
\text { Commitment } \\
\text {-Peer Support }\end{array}$ & $\begin{array}{l}\text { The findings of } \\
\text { this study } \\
\text { supported that } \\
\text { social exchange } \\
\text { theory (SET) can } \\
\text { be used as a } \\
\text { theoretical } \\
\text { framework } \\
\text { understanding the } \\
\text { construct } \\
\text { employee } \\
\text { engagement and } \\
\text { retention. }\end{array}$ \\
\hline $\begin{array}{l}\text { Muhammad } \\
\text { Imran Hanif } \\
\text { and Shao } \\
\text { Yunfei }{ }^{[58]} \\
\text { (2013) }\end{array}$ & $\begin{array}{l}\text { H1: The } \\
\text { Implementation of } \\
\text { talent management } \\
\text { strategies along with } \\
\text { HR practices helps in } \\
\text { retaining employees } \\
\text { for long periods of } \\
\text { time. }\end{array}$ & $\begin{array}{l}\text { The sample size of } \\
200 \text { respondents was } \\
\text { undertaken and the } \\
\text { questionnaire was } \\
\text { floated to HR } \\
\text { managers at } \\
\text { different levels.( } \\
\text { Chengdu-Republic } \\
\text { of China) }\end{array}$ & $\begin{array}{l}\text {-Succession planning } \\
\text {-Employer's branding } \\
\text {-Motivation } \\
\text { development policies } \\
\text {-Training and } \\
\text { development }\end{array}$ & $\begin{array}{l}\text { Findings of the } \\
\text { above research } \\
\text { that the } \\
\text { effectiveness of a } \\
\text { brand signal to } \\
\text { potential } \\
\text { employees is } \\
\text { dependent on the } \\
\text { consistency, } \\
\text { clarity, credibility, } \\
\text { and associated } \\
\text { investments in the } \\
\text { employer brand. }\end{array}$ \\
\hline $\begin{array}{l}\text { Daisy } \\
\text { Ofosuhene } \\
\text { Kwenin, } \\
\text { Stephen } \\
\text { Muathe, } \\
\text { Robert } \\
\text { Nzulwa }{ }^{[59]} \\
\\
\text { (2013) }\end{array}$ & $\begin{array}{l}\text { The study aims to } \\
\text { determine } \\
\text { association between } \\
\text { rewards } \\
\text { employee retention } \\
\text { and also to Assess the } \\
\text { influence of job } \\
\text { satisfaction } \\
\text { employees, intention } \\
\text { to stay with Vodafone } \\
\text { Ghana. }\end{array}$ & $\begin{array}{l}\text { The sample size was } \\
142 \text { employees } \\
\text { representing } 10 \% \text { of } \\
\text { the target } \\
\text { population. } \\
\text { (Vodafone Limited. } \\
\text { Ghana) }\end{array}$ & $\begin{array}{l}\text {-Employee Rewards } \\
\text {-Recognition Programs } \\
\text {-Job Satisfaction }\end{array}$ & $\begin{array}{l}\text { The empirical } \\
\text { review showed } \\
\text { that in order for } \\
\text { organizations to } \\
\text { do a better work in } \\
\text { retaining } \\
\text { employees they } \\
\text { should understand } \\
\text { the factors that } \\
\text { motivate } \\
\text { employees. }\end{array}$ \\
\hline $\begin{array}{l}\text { Felicity } \\
\text { Asiedu- } \\
\text { Appiah, Eric } \\
\text { Kontor and } \\
\text { David } \\
\text { Asamoah }{ }^{[60]} \\
\text { (2013) }\end{array}$ & $\begin{array}{l}\text { The study was to } \\
\text { identify frequently } \\
\text { used human resource } \\
\text { management } \\
\text { activities in the } \\
\text { mining industry in } \\
\text { Ghana and their } \\
\text { effect on employee } \\
\text { retention. }\end{array}$ & $\begin{array}{l}\text { The Questionnaires } \\
\text { and interviews were } \\
\text { used to collect data } \\
\text { from a sample of } \\
\text { one hundred and } \\
\text { fifty (150) } \\
\text { respondents. } \\
\text { (Ghana) }\end{array}$ & 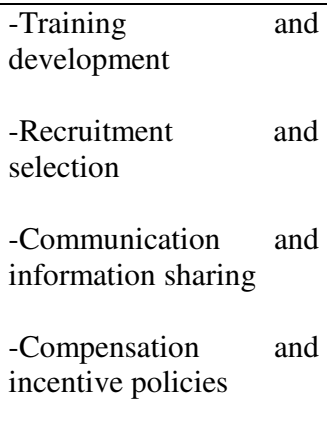 & $\begin{array}{l}\text { Human resource } \\
\text { management } \\
\text { practices like } \\
\text { Communication } \\
\text { and Compensation } \\
\text { were frequently } \\
\text { practiced and } \\
\text { evaluated within } \\
\text { the company to } \\
\text { access the } \\
\text { employee } \\
\text { retention. }\end{array}$ \\
\hline Dorothea & This study tested the & sample & -Employee engagement & Employee \\
\hline
\end{tabular}


International Journal of BRIC Business Research (IJBBR) Volume 6, Number 1, February 2017

\begin{tabular}{|c|c|c|c|c|}
\hline $\begin{array}{l}\text { Wahyu } \\
\text { Ariani }{ }^{61]} \\
\text { (2013) }\end{array}$ & $\begin{array}{l}\text { relationship between } \\
\text { employee } \\
\text { engagement, } \\
\text { organizational } \\
\text { citizenship behavior } \\
\text { (OCB) and } \\
\text { counterproductive } \\
\text { work behavior } \\
\text { (CWB). }\end{array}$ & 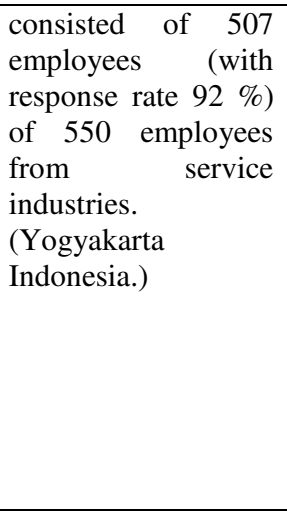 & $\begin{array}{l}\text {-Organizational } \\
\text { citizenship behavior } \\
\text {-Counterproductive } \\
\text { work behavior }\end{array}$ & $\begin{array}{l}\text { engagement is } \\
\text { related positively } \\
\text { to OCB and } \\
\text { negatively to } \\
\text { CWB but OCB } \\
\text { and CWB are the } \\
\text { separate } \\
\text { constructs. } \\
\text { Organizationally } \\
\text { directed OCB and } \\
\text { CWB are different } \\
\text { types of behavior } \\
\text { because CWB is } \\
\text { opposed to OCB. }\end{array}$ \\
\hline $\begin{array}{l}\text { Silvia } \\
\text { Simbula and } \\
\text { Dina } \\
\text { Guglielmi }{ }^{[62]} \\
\text { (2013) }\end{array}$ & $\begin{array}{l}\text { The purpose of the } \\
\text { present study was to } \\
\text { examine longitudinal } \\
\text { relationships between } \\
\text { work engagement and } \\
\text { mental-health } \\
\text { problems, job } \\
\text { satisfaction and extra- } \\
\text { role performance. }\end{array}$ & $\begin{array}{l}\text { This study was } \\
\text { conducted among } \\
157 \text { schoolteachers, } \\
\text { and the time lag was } \\
\text { of five months on } \\
\text { average. (Italy) }\end{array}$ & $\begin{array}{l}\text {-Work engagement } \\
\text {-Mental-health problems } \\
\text {-Job satisfaction } \\
\text {-Work engagement } \\
\text {-Job satisfaction }\end{array}$ & $\begin{array}{l}\text { The findings } \\
\text { indicated that the } \\
\text { relationships } \\
\text { among work } \\
\text { engagement, well- } \\
\text { being and } \\
\text { contextual } \\
\text { performance are } \\
\text { best explained } \\
\text { when both causal } \\
\text { and reversed- } \\
\text { causal } \\
\text { relationships are } \\
\text { taken into account. }\end{array}$ \\
\hline $\begin{array}{l}\text { Salman } \\
\text { Habib, Saira } \\
\text { Aslam, } \\
\text { Amjad } \\
\text { Hussain, } \\
\text { Sana } \\
\text { Yasmeen, } \\
\text { Muhammad } \\
\text { Ibrahim }{ }^{[63]} \\
\text { (2014) }\end{array}$ & $\begin{array}{l}\text { The study aims to } \\
\text { explore the impact of } \\
\text { organizational culture } \\
\text { on the job } \\
\text { satisfaction, } \\
\text { employee's } \\
\text { commitment and the } \\
\text { retention of the } \\
\text { employees in the } \\
\text { organizations. }\end{array}$ & $\begin{array}{l}\text { The data was } \\
\text { collected through } \\
\text { questionnaire } \\
\text { consisting of } 24 \\
\text { questions; the } \\
\text { sample consisted of } \\
235 \text { employees of } \\
\text { different } \\
\text { Organizations. } \\
\text { (Punjab, Pakistan.) }\end{array}$ & $\begin{array}{l}\text {-Organizational Culture, } \\
\text {-Employees, } \\
\text { Commitment, } \\
\text {-Employees, Retention, } \\
\text {-Job Satisfaction }\end{array}$ & $\begin{array}{l}\text { The research } \\
\text { conclude that there } \\
\text { is positive and } \\
\text { significant } \\
\text { correlation among } \\
\text { Impact of } \\
\text { organizational } \\
\text { culture } \\
\text { employees } \\
\text { commitment, job } \\
\text { satisfaction and } \\
\text { employees } \\
\text { retention. }\end{array}$ \\
\hline $\begin{array}{l}\text { Tangthong, } \\
\text { Sorasak } \\
\text { (2014) }\end{array}$ & $\begin{array}{l}\text { The purpose of this } \\
\text { study is to determine } \\
\text { the effects of human } \\
\text { resource management } \\
\text { (HRM) practices on } \\
\text { employee retention in } \\
\text { Thailand's } \\
\text { multinational } \\
\text { corporations (MNCs) }\end{array}$ & $\begin{array}{l}\text { A total of } 411 \\
\text { managers, consisting } \\
\text { of top management, } \\
\text { HR leader and line } \\
\text { manager, were } \\
\text { examined for the } \\
\text { study. (MNCs in } \\
\text { Thailand) }\end{array}$ & $\begin{array}{l}\text {-Employee Motivation } \\
\text {-HR Flexibility } \\
\text {-Organizational } \\
\text { Citizenship Behaviors } \\
\text {-Training and } \\
\text { Development } \\
\text {-Compensation and } \\
\text { Benefits }\end{array}$ & $\begin{array}{lr}\begin{array}{l}\text { Results } \\
\text { shown a }\end{array} & \text { have } \\
\text { correlation } & \\
\text { between } & \text { HRM } \\
\text { practices } & \text { and } \\
\text { employee } & \\
\text { retention. This } \\
\text { proves useful to } \\
\text { firms that aim to } \\
\text { keep employees in } \\
\text { their organizations } \\
\text { for longer periods. }\end{array}$ \\
\hline Madelyn & The aim of the study & The sample $(n=$ & -Psychological & Result of the study \\
\hline
\end{tabular}


International Journal of BRIC Business Research (IJBBR) Volume 6, Number 1, February 2017

\begin{tabular}{|c|c|c|c|c|}
\hline $\begin{array}{l}\text { Geldenhuys } \\
\text { Karolina } \\
\text { Laba } \\
\text { Cornelia M. } \\
\text { Venter }^{[65]} \\
\text { (2014) }\end{array}$ & $\begin{array}{l}\text { was to investigate the } \\
\text { relationships amongst } \\
\text { psychological } \\
\text { meaningfulness, work } \\
\text { engagement and } \\
\text { organizational } \\
\text { commitment. }\end{array}$ & $\begin{array}{l}\text { 415) consisted of } \\
\text { working employees } \\
\text { from } \\
\text { companies. } \\
\text { (Gauteng, } \\
\text { Africa.) }\end{array}$ & $\begin{array}{l}\text { meaningfulness } \\
\text {-Work engagement and } \\
\text {-Organizational } \\
\text { commitment. }\end{array}$ & $\begin{array}{l}\text { confirmed a } \\
\text { positive } \\
\text { relationship } \\
\text { between } \\
\text { psychological } \\
\text { meaningfulness } \\
\text { work engagement } \\
\text { and organizational } \\
\text { commitment. }\end{array}$ \\
\hline $\begin{array}{lr}\text { Bruce } & \text { A. } \\
\text { Raytona } & \& \\
\text { Zayne } & \text { Y. } \\
\text { Yalabika } & {[66]} \\
& \\
(\mathbf{2 0 1 4}) & \end{array}$ & $\begin{array}{l}\text { To examining and } \\
\text { explore the link } \\
\text { between } \\
\text { psychological } \\
\text { contract breach } \\
\text { (PCB) and work } \\
\text { engagement and by } \\
\text { integrating job } \\
\text { satisfaction into this } \\
\text { exchange } \\
\text { relationship. }\end{array}$ & $\begin{array}{l}\text { The Data was } \\
\text { collected via } \\
\text { questionnaires \& } \\
\text { survey data from } \\
191 \text { employees.( } \\
\begin{array}{l}\text { Specialist lending } \\
\text { division of a UK } \\
\text { bank) }\end{array}\end{array}$ & $\begin{array}{l}\text {-Work engagement and } \\
\text { psychological contract } \\
\text { breach } \\
\text {-Job satisfaction } \\
\text {-Psychological }\end{array}$ & $\begin{array}{l}\text { The analyses of } \\
\text { study support the } \\
\text { hypothesized } \\
\text { mediation of the } \\
\text { relationship } \\
\text { between PCB and } \\
\text { work engagement } \\
\text { by job satisfaction } \\
\text { and indicating that } \\
\text { work engagement } \\
\text { is more likely to } \\
\text { occur when } \\
\text { employees feel } \\
\text { that their } \\
\text { organizations are } \\
\text { meeting their } \\
\text { obligations. }\end{array}$ \\
\hline $\begin{array}{l}\text { Jackson M.E. } \\
\text { Muhoho }{ }^{[67]} \\
\text { (2014) }\end{array}$ & $\begin{array}{l}\text { To reveal and assess } \\
\text { the factors perceived } \\
\text { by employees as } \\
\text { forces influencing } \\
\text { retention at the } \\
\text { Workplace. }\end{array}$ & $\begin{array}{lr}\text { This present } & \text { study } \\
\text { used a sample of } 60 \\
\text { respondents } & \text { drawn } \\
\text { from ten } & (10) \\
\text { selected } & \\
\text { organizations } & \text { in } \\
\text { Tanzania. } & \\
\text { (Tanzania's } & \text { public } \\
\text { and private } & \text { sector } \\
\text { workplaces.) } & \end{array}$ & $\begin{array}{l}\text {-Salary and Benefits } \\
\text {-Retirement Plans } \\
\text {-Development } \\
\text { Opportunities }\end{array}$ & $\begin{array}{l}\text { The study stated } \\
\text { that companies } \\
\text { and employers } \\
\text { should work hard } \\
\text { towards achieving } \\
\text { a highly teamed } \\
\text { up workplace and } \\
\text { organizations } \\
\text { through } \\
\text { integrating and } \\
\text { alignment of } \\
\text { organizational } \\
\text { goals } \\
\text { individual with } \\
\text { employee. }\end{array}$ \\
\hline $\begin{array}{l}\text { Aerni Isa, } \\
\text { Hazril Izwar } \\
\text { Ibrahim }^{[68]} \\
\text { (2014) }\end{array}$ & $\begin{array}{l}\text { The main objective of } \\
\text { this paper is to } \\
\text { understand } \\
\text { influence of talent } \\
\text { management } \\
\text { practices } \\
\text { employee } \\
\text { engagement. }\end{array}$ & $\begin{array}{l}\text { The Sample size was } \\
495 \text { employees of } \\
\text { GLCs. Systematic } \\
\text { sampling technique } \\
\text { was used. } \\
\text { Malaysia) }\end{array}$ & $\begin{array}{l}\text {-Employees } \\
\text { psychological } \\
\text { connection } \\
\\
\text {-Development } \\
\text { Opportunities } \\
\\
\text {-Extensive } \\
\text { training } \\
\text {-Comprehensive career } \\
\text { planning }\end{array}$ & $\begin{array}{l}\text { Study concluded } \\
\text { that by providing } \\
\text { an employee with } \\
\text { a development } \\
\text { plan which } \\
\text { includes } \\
\text { structuring } \\
\text { competencies and } \\
\text { skills which an } \\
\text { employee can } \\
\text { develop would } \\
\text { lead to increased } \\
\text { work engagement. }\end{array}$ \\
\hline $\begin{array}{l}\text { Madhura } \\
\text { Bedarkar, }\end{array}$ & $\begin{array}{l}\text { The study explores } \\
\text { the concept of }\end{array}$ & $\begin{array}{l}\text { A model has been } \\
\text { conceptualized }\end{array}$ & -Communication & $\begin{array}{l}\text { The study showed } \\
\text { that employees are }\end{array}$ \\
\hline
\end{tabular}


International Journal of BRIC Business Research (IJBBR) Volume 6, Number 1, February 2017

\begin{tabular}{|c|c|c|c|c|}
\hline $\begin{array}{l}\text { Deepika } \\
\text { Pandita }{ }^{[69]} \\
\text { (2014) }\end{array}$ & $\begin{array}{l}\text { employee } \\
\text { engagement and also } \\
\text { throws light on key } \\
\text { drivers of employee } \\
\text { engagement. }\end{array}$ & 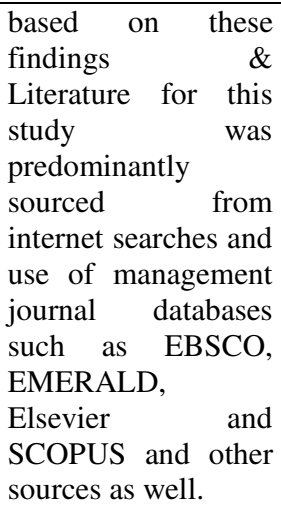 & $\begin{array}{l}\text {-Work life balance } \\
\text {-Leadership }\end{array}$ & $\begin{array}{l}\text { the key assets to } \\
\text { any organization } \\
\text { and if they are not } \\
\text { given the right } \\
\text { space and time to } \\
\text { make a perfect } \\
\text { blend of work and } \\
\text { fun at workplace } \\
\text { then the sense of } \\
\text { dis-engagement } \\
\text { sets in the } \\
\text { employees. }\end{array}$ \\
\hline $\begin{array}{l}\text { Kimberley } \\
\text { Breevaart, } \\
\text { Arnold B. } \\
\text { Bakker, } \\
\text { Evangelia } \\
\text { Demerouti } \\
\text { [70] } \\
\\
\text { (2014) }\end{array}$ & $\begin{array}{l}\text { To examining how } \\
\text { Self-management is } \\
\text { related to employees } \\
\text { work engagement on } \\
\text { a daily basis } \\
\text { activities. }\end{array}$ & $\begin{array}{l}162 \text { maternity nurses } \\
\text { were approached to } \\
\text { participate in the } \\
\text { study. After five } \\
\text { weeks, } 72 \text { nurses } \\
\text { filled out the } \\
\text { questionnaires. } \\
\text { Saudi Arabia) }\end{array}$ & $\begin{array}{l}\text {-Working conditions, } \\
\text {-Work-role fit, } \\
\text {-Career advancement, } \\
\text {-Job Satisfaction } \\
\text {-Job performance } \\
\text {-Salary Structure }\end{array}$ & $\begin{array}{l}\text { Finding of various } \\
\text { studies show that } \\
\text { employee } \\
\text { engagement is } \\
\text { positively related } \\
\text { job performance, } \\
\text { incentives/improv } \\
\text { ed salaries, weekly } \\
\text { meetings, } \\
\text { employee core } \\
\text { self-evaluations, } \\
\text { employee } \\
\text { psychological } \\
\text { climate } \\
\text { organizational } \\
\text { commitment. }\end{array}$ \\
\hline $\begin{array}{l}\text { Maniam } \\
\text { Kaliannana, } \\
\text { Samuel Narh } \\
\text { Adjovu }{ }^{771]} \\
\text { (2015) }\end{array}$ & $\begin{array}{l}\text { This paper explores } \\
\text { the strengths and } \\
\text { weaknesses of } \\
\text { employee } \\
\text { engagement strategies } \\
\text { implemented by a } \\
\text { telecommunications } \\
\text { organization in } \\
\text { Ghana. }\end{array}$ & $\begin{array}{l}\text { A Quantitative } \\
\text { research approach } \\
\text { was adopted with } \\
137 \text { completed } \\
\text { Responses .(Ghana) }\end{array}$ & $\begin{array}{l}\text {-Work Environment } \\
\text {-HRM Practices } \\
\text { - Employee-Supervisor } \\
\text { Relationship } \\
\text {-Job Satisfaction } \\
\text {-Organizational Culture }\end{array}$ & $\begin{array}{l}\text { The results } \\
\text { captured the health } \\
\text { of the work } \\
\text { environment as } \\
\text { sane and sound. } \\
\text { With HRM } \\
\text { practices in their } \\
\text { most attractive } \\
\text { package presented. } \\
\text { The employee- } \\
\text { supervisor } \\
\text { relationship could } \\
\text { not go haywire. }\end{array}$ \\
\hline $\begin{array}{l}\text { Maqsood } \\
\text { Haider, } \\
\text { Amran Rasli, } \\
\text { ChaudhrySho } \\
\text { aib Akhtar } \\
{[72]} \\
\text { (2015) }\end{array}$ & 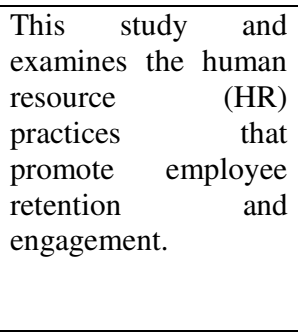 & $\begin{array}{l}\text { The sample size of } \\
\text { this study was } 250 \text {. }\end{array}$ & $\begin{array}{l}\text {-Training and } \\
\text { development } \\
\text {-Compensation } \\
\text {-Organization Culture } \\
\text {-Retention }\end{array}$ & $\begin{array}{l}\text { Research showed } \\
\text { that the employees } \\
\text { feel that effective } \\
\text { HR practices have } \\
\text { a direct and } \\
\text { positive } \\
\text { relationship with } \\
\text { employee } \\
\text { retention. }\end{array}$ \\
\hline $\begin{array}{l}\text { Margaret } \\
\text { Deery, Leo } \\
\text { Jago }{ }^{[73]}\end{array}$ & $\begin{array}{l}\text { This paper aims to } \\
\text { examine the themes } \\
\text { of } \\
\text { management, work- }\end{array}$ & Conceptual Study & $\begin{array}{l}\text { Job satisfaction, } \\
\text { Organizational } \\
\text { commitment }\end{array}$ & $\begin{array}{l}\text { Review conducted } \\
\text { that updated } \\
\text { framework that } \\
\text { was presented }\end{array}$ \\
\hline
\end{tabular}


International Journal of BRIC Business Research (IJBBR) Volume 6, Number 1, February 2017

\begin{tabular}{|c|c|c|c|c|}
\hline (2015) & $\begin{array}{l}\text { life balance (WLB) } \\
\text { and retention } \\
\text { strategies in the } \\
\text { organization in hotel } \\
\text { industry. }\end{array}$ & & $\begin{array}{l}\text { Employee } \\
\text { retention }\end{array}$ & $\begin{array}{l}\text { suggests that } \\
\text { employee attitudes } \\
\text { such as job and } \\
\text { pay satisfaction or } \\
\text { work overload will } \\
\text { impact on WLB as } \\
\text { will personal } \\
\text { dimensions such } \\
\text { as stress and } \\
\text { substance abuse. }\end{array}$ \\
\hline $\begin{array}{l}\text { Yogendra } \\
\text { Bhattcharya } \\
{[74]} \\
\text { (2015) }\end{array}$ & $\begin{array}{l}\text { Study aims to } \\
\text { understand how } \\
\text { satisfied officers were } \\
\text { with their employers } \\
\text { and employment } \\
\text { conditions and to } \\
\text { determine the drivers } \\
\text { of retention in the } \\
\text { maritime industry, } \\
\text { and to assess if these } \\
\text { were in line with } \\
\text { those found in } \\
\text { literature reviews. }\end{array}$ & $\begin{array}{l}220 \text { Indian Officers } \\
\text { in shipping \& } \\
\text { logistics industry. }\end{array}$ & $\begin{array}{l}\text { Culture } \\
\text { Health \& Safety } \\
\text { Turnover } \\
\text { Working Conditions } \\
\text { Empowerment }\end{array}$ & $\begin{array}{l}\text { Study concluded } \\
\text { that retention } \\
\text { levels of officers } \\
\text { are low with the } \\
\text { majority not } \\
\text { finding } \\
\text { employment } \\
\text { conditions } \\
\text { conducive to long } \\
\text { time service with } \\
\text { their current } \\
\text { organizations. } \\
\text { There are many } \\
\text { areas where ship } \\
\text { owners and } \\
\text { managers can } \\
\text { improve which } \\
\text { can increase } \\
\text { seafarer } \\
\text { engagement as } \\
\text { well as their } \\
\text { retention. }\end{array}$ \\
\hline $\begin{array}{l}\text { Mariyam } \\
\text { Imna, } \\
\text { Zubair } \\
\text { Hassan }{ }^{[75]} \\
\text { (2015) }\end{array}$ & $\begin{array}{l}\text { To examine the effect } \\
\text { of reward and } \\
\text { compensation on } \\
\text { employee retention } \\
\text { and engagement. }\end{array}$ & $\begin{array}{l}\text { The study used a } \\
\text { survey } \\
\text { Questionnaires } \\
\text { containing } 30 \text { items } \\
\text { with Likert Scale } \\
\text { (Disagree }-1 \text { and } 5 \\
\text { for Agree). The } \\
\text { sample of } 254 \\
\text { employees from } 14 \\
\text { retail outlets in } \\
\text { Male' were selected } \\
\text { using convenient } \\
\text { sampling.(Capital } \\
\text { city of Maldives) }\end{array}$ & $\begin{array}{l}\text {-HR Practices, } \\
\text {-Career } \\
\text { Development, } \\
\text {-Training and } \\
\text { development, } \\
\text {-Performance } \\
\text { Appraisal, } \\
\text {-Reward } \\
\text { compensation, } \\
\text {-Health and } \\
\text { Safety, }\end{array}$ & $\begin{array}{l}\text { The result of the } \\
\text { paper showed that } \\
\text { there is a positive } \\
\text { and significant } \\
\text { influence of career } \\
\text { development on } \\
\text { employee } \\
\text { retention even } \\
\text { though career } \\
\text { development is not } \\
\text { often practices } \\
\text { among the } \\
\text { organizations. }\end{array}$ \\
\hline $\begin{array}{ll}\text { Simon } & \text { L. } \\
\text { Albrecht } & \\
\text { Arnold } & \text { B. } \\
\text { Bakker } & \\
\text { Jamie } & \text { A. } \\
\text { Gruman } & \\
\text { William } & \text { H. } \\
\text { Macey } & \\
\end{array}$ & $\begin{array}{l}\text { The aim of this paper } \\
\text { is to argue in support } \\
\text { of a model that shows } \\
\text { how four key HRM } \\
\text { practices focused on } \\
\text { engagement influence } \\
\text { organizational } \\
\text { climate, job demands }\end{array}$ & Conceptual Study & $\begin{array}{l}\text {-Engagement } \\
\text {-Personnel selection, } \\
\text {-Socialization, } \\
\text {-Performance } \\
\text { management, }\end{array}$ & $\begin{array}{l}\text { This result } \\
\text { concluded that } \\
\text { engagement } \\
\text { provides } \\
\text { conceptually well- } \\
\text { developed and } \\
\text { well-researched } \\
\text { strategy by which }\end{array}$ \\
\hline
\end{tabular}


International Journal of BRIC Business Research (IJBBR) Volume 6, Number 1, February 2017

\begin{tabular}{|c|c|c|c|c|}
\hline $\begin{array}{l}\text { Alan M. Saks } \\
{[76]} \\
\text { (2015) }\end{array}$ & and job resources. & & $\begin{array}{l}\text {-Training } \\
\text { development }\end{array}$ & $\begin{array}{l}\text { competitive } \\
\text { advantage can be } \\
\text { achieved, } \\
\text { developed and } \\
\text { maintained. This } \\
\text { paper showed that } \\
\text { HRM content and } \\
\text { process must be } \\
\text { integrated } \\
\text { effectively in } \\
\text { order } \\
\text { prescriptive for } \\
\text { models of strategic } \\
\text { HRM }\end{array}$ \\
\hline $\begin{array}{l}\text { Lucia } \\
\text { Barbosa de } \\
\text { Oliveira, } \\
\text { Fernanda } \\
\text { Flôres } \\
\text { Roitman } \\
\text { Aguiar }_{\text {Silva }}^{[77]} \\
\\
\text { (2015) }\end{array}$ & $\begin{array}{l}\text { The study aims to } \\
\text { evaluate the effects of } \\
\text { high performance } \\
\text { work systems } \\
\text { (HPWS) and leader- } \\
\text { member exchange } \\
\text { (LMX) quality on } \\
\text { employee } \\
\text { engagement and also } \\
\text { to examine the } \\
\text { relationship between } \\
\text { employee } \\
\text { engagement and } \\
\text { turnover intention of } \\
\text { employees. }\end{array}$ & $\begin{array}{lr}\text { The } & \text { research } \\
\text { involved } & 189 \\
\text { employees. } \\
\text { (Brazilian } \\
\text { organization.) }\end{array}$ & $\begin{array}{l}\text {-Recruitment } \begin{array}{l}\text { selection } \\
\text {-Training } \\
\text { development }\end{array} \\
\text {-Motivation and } \\
\text { effort } \\
\text {-Performance } \\
\text { management, } \\
\text {-Compensation, } \\
\text {-Job security policy } \\
\text {-Opportunities to } \\
\text { contribute }\end{array}$ & $\begin{array}{l}\text { Results of this } \\
\text { study conducted in } \\
\text { a large Brazilian } \\
\text { non-profit } \\
\text { organization } \\
\text { revealed that } \\
\text { HPWS and LMX } \\
\text { quality were } \\
\text { positively related } \\
\text { to employee } \\
\text { engagement }\end{array}$ \\
\hline $\begin{array}{l}\text { Marie } \\
\text { Carasco-Saul, } \\
\text { Woocheol } \\
\text { Kim, } \\
\text { Taesung Kim } \\
\text { [78] } \\
\text { (2015) }\end{array}$ & $\begin{array}{l}\text { To Understand the } \\
\text { relationship between } \\
\text { leadership and } \\
\text { employee } \\
\text { engagement, } \\
\text { analyzed/ synthesized } \\
\text { the studies into } \\
\text { integrated } \\
\text { frameworks for the } \\
\text { leadership- } \\
\text { engagement } \\
\text { relationship. }\end{array}$ & $\begin{array}{l}\text { This study used } \\
\text { multiple databases } \\
\text { encompassing } 39 \\
\text { smaller database } \\
\text { subsets (e.g., } \\
\text { ABI/INFORM } \\
\text { Complete, ProQuest } \\
\text { Education Journals, } \\
\text { PsycINFO, and } \\
\text { Psyc ARTICLES) to } \\
\text { extract as many } \\
\text { relevant articles for } \\
\text { the study. }\end{array}$ & $\begin{array}{l}\text {-Authentic leadership \& } \\
\text { Engagement } \\
\text {-Ethical leadership \& } \\
\text { Engagement } \\
\\
\text {-Transformational } \\
\text { leadership \& } \\
\text { Engagement }\end{array}$ & $\begin{array}{l}\text { There were four } \\
\text { distinct } \\
\text { instruments to } \\
\text { measure } \\
\text { leadership: (1) the } \\
\text { Multifactor } \\
\text { Leadership } \\
\text { Questionnaire } \\
\text { (MLQ) for } \\
\text { transformational } \\
\text { leadership, (2) } \\
\text { authentic } \\
\text { leadership using } \\
\text { the 16-item ALQ } \\
\text { for authentic } \\
\text { leadership, (3) the } \\
\text { 10-item Ethical } \\
\text { Leadership Scale } \\
\text { (ELS) for ethical } \\
\text { leadership, and (4) } \\
\text { the 20-item } \\
\text { Conger-Kanungo } \\
\text { Charismatic } \\
\text { Leadership Scale }\end{array}$ \\
\hline
\end{tabular}


International Journal of BRIC Business Research (IJBBR) Volume 6, Number 1, February 2017

\begin{tabular}{|c|c|c|c|c|}
\hline & & & & $\begin{array}{l}\text { for charismatic } \\
\text { leadership was } \\
\text { identified. }\end{array}$ \\
\hline $\begin{array}{l}\text { Safiah } \\
\text { Rashid, } \\
\text { Mohd Amy } \\
\text { Azhar bin, } \\
\text { Mohd Harif } \\
\text { [79] } \\
\\
\text { (2015) }\end{array}$ & $\begin{array}{l}\text { To explore the vital } \\
\text { factors of employee } \\
\text { engagement and their } \\
\text { outcomes at } \\
\text { organizational and } \\
\text { individual levels. }\end{array}$ & $\begin{array}{l}\text { Personal interview } \\
\text { technique will } \\
\text { constitute the } \\
\text { methodology of this } \\
\text { research for primary } \\
\text { data collection. } \\
\text { Snowball sampling } \\
\text { technique was used. } \\
\text { (Malaysia) }\end{array}$ & $\begin{array}{l}\text { Productivity } \\
\text { Business Growth }\end{array}$ & $\begin{array}{l}\text { By identifying the } \\
\text { critical factors of } \\
\text { organizational- } \\
\text { level outcomes, it } \\
\text { will help the top } \\
\text { management of } \\
\text { SMEs and the } \\
\text { policymakers to } \\
\text { optimize } \\
\text { employee } \\
\text { engagement and to } \\
\text { propose well- } \\
\text { designed support } \\
\text { programs and } \\
\text { strategies for } \\
\text { performance } \\
\text { improvement in } \\
\text { SMEs. }\end{array}$ \\
\hline $\begin{array}{l}\text { Dr. Hammad } \\
\text { Alshammari } \\
{[80]}\end{array}$ & $\begin{array}{l}\text { To current study aims } \\
\text { understand the scope } \\
\text { and importance of } \\
\text { employee } \\
\text { engagement in } \\
\text { various organizations } \\
\text { and to determine the } \\
\text { factors enhancing } \\
\text { employee } \\
\text { engagement level }\end{array}$ & $\begin{array}{l}\text { The study reviews } \\
\text { the literatures of } \\
\text { various past relevant } \\
\text { research studies \& } \\
\text { conceptual points as } \\
\text { well. (Saudi Arabia). }\end{array}$ & $\begin{array}{l}\text {-Co-worker } \\
\text { Relationship } \\
\text {-Rewards \& recognition } \\
\text {-Working conditions } \\
\text { Work-role fit } \\
\text {-Career advancement } \\
\text {-Job Satisfaction }\end{array}$ & $\begin{array}{l}\text { The result } \\
\text { concluded that } \\
\text { Employee } \\
\text { Training } \\
\text { development, \& } \\
\text { Supervisor's } \\
\text { support, Team \& } \\
\text { Co-worker } \\
\text { Relationship, } \\
\text { Rewards } \\
\text { \&recognition, } \\
\text { Working } \\
\text { conditions, Work- } \\
\text { role fit. }\end{array}$ \\
\hline $\begin{array}{l}\text { Eric Ng Chee } \\
\text { Hong, Lam } \\
\text { Zheng Hao, } \\
\text { Ramesh } \\
\text { Kumar, } \\
\text { Charles } \\
\text { Ramendran, } \\
\text { Vimala } \\
\text { Kadiresan }{ }^{[81]} \\
\text { (2016) }\end{array}$ & $\begin{array}{l}\text { The main objective of } \\
\text { this study is to see the } \\
\text { effectiveness of } \\
\text { existing training } \\
\text { programs, employee } \\
\text { empowerment, job } \\
\text { appraisal and } \\
\text { compensation in } \\
\text { retaining \& engaging } \\
\text { the employee: From, } \\
\text { the academicians' } \\
\text { perception. }\end{array}$ & $\begin{array}{l}\text { Quantitative data } \\
\text { was collected using } \\
\text { the non-probability } \\
\text { self-administered } \\
\text { questionnaire that } \\
\text { consist of Questions } \\
\text { with 5-points Likert } \\
\text { scales distributed to } \\
278 \text { individuals for } \\
\text { the study. } \\
\text { (Malaysian } \\
\text { University) }\end{array}$ & $\begin{array}{l}\text {-Employee } \\
\text { empowerment } \\
\text {-Training } \\
\text { development, } \\
\text {-Employee } \\
\text { compensation } \\
\text {-Performance } \\
\text { appraisal }\end{array}$ & $\begin{array}{l}\text { The result showed } \\
\text { that, there is } \\
\text { highly significant } \\
\text { relationship } \\
\text { between the } \\
\text { factors of training, } \\
\text { compensation and } \\
\text { appraisal on } \\
\text { University of Z } \\
\text { lecturer's retention } \\
\text { \& engagement. }\end{array}$ \\
\hline $\begin{array}{l}\text { Daniel } \\
\text { Pittino, } \\
\text { Francesca } \\
\text { Visintinb, } \\
\text { Tamara } \\
\text { Lenger, } \\
\text { Dietmar } \\
\text { Sternad }{ }^{[82]}\end{array}$ & $\begin{array}{l}\text { The present study } \\
\text { identify the adoption } \\
\text { of high-performance } \\
\text { work practices } \\
\text { (HPWPs) in family } \\
\text { versus non-family } \\
\text { firms. }\end{array}$ & $\begin{array}{l}\text { A questionnaire \& e- } \\
\text { mails with a link to } \\
\text { the online survey } \\
\text { instrument was } \\
\text { designed and sent to } \\
1649 \text { managers ( } 917 \\
\text { in Austria, } 732 . \\
\text { (Hungary). }\end{array}$ & $\begin{array}{l}\text {-High Performance } \\
\text { Work Practices } \\
\text { (HPWPs): } \\
\text {-Selective staffing } \\
\text { - Intensive training } \\
\text {-Career development }\end{array}$ & $\begin{array}{l}\text { The family firm } \\
\text { status and the } \\
\text { conditions } \\
\text { strengthening the } \\
\text { family influence } \\
\text { on the firm have a } \\
\text { positive impact on } \\
\text { retention and } \\
\text { engagement. }\end{array}$ \\
\hline
\end{tabular}


International Journal of BRIC Business Research (IJBBR) Volume 6, Number 1, February 2017

\begin{tabular}{|c|c|c|c|c|}
\hline (2016) & & & $\begin{array}{l}\text {-Extensive } \\
\text { compensation and } \\
\text { benefits } \\
\text {-Performance appraisals }\end{array}$ & \\
\hline $\begin{array}{l}\text { Dr. A } \\
\text { Kumudha, } \\
\text { Harsha KJ }{ }^{[83]} \\
\text { (2016) }\end{array}$ & $\begin{array}{l}\text { To find the } \\
\text { relationship between } \\
\text { employees retention } \\
\text { with regard to HRM } \\
\text { practices, Job } \\
\text { Satisfaction and } \\
\text { Organizational } \\
\text { Commitment within } \\
\text { the organization. }\end{array}$ & \begin{tabular}{ll}
\multicolumn{2}{l}{ Semi-structured } \\
questionnaire was \\
designed for 437 \\
respondents & was \\
used to collect data. \\
(Jebel Ali \\
International \\
Hospital in Dubai.)
\end{tabular} & $\begin{array}{l}\text {-HR Practices, } \\
\text {-Job Satisfaction, } \\
\text {-Organizational } \\
\text { Commitment } \\
\text {-Intent to } \\
\text { Leave/ Stay }\end{array}$ & $\begin{array}{l}\text { Key factors which } \\
\text { affects employee } \\
\text { retention in UAE } \\
\text { organizations are } \\
\text { as the leadership } \\
\text { style of top } \\
\text { managers, fairness } \\
\text { in the treatment } \\
\text { accorded to } \\
\text { employees by their } \\
\text { supervisors a clear } \\
\text { understanding. }\end{array}$ \\
\hline $\begin{array}{l}\text { Arti } \\
\text { Chandani, } \\
\text { Mita Mehta, } \\
\text { Akanksha } \\
\text { Mall and } \\
\text { Vashwee } \\
\text { Khokhar }^{[84]} \\
\text { (2016) }\end{array}$ & $\begin{array}{l}\text { This present study } \\
\text { aims to clarify and } \\
\text { identify what is } \\
\text { employee } \\
\text { engagement and what } \\
\text { is its importance on } \\
\text { employee retention }\end{array}$ & Conceptual Study & $\begin{array}{l}\text {-Career Development } \\
\text {-Leadership } \\
\text {-Clarity of Company } \\
\text { Values, Policies and } \\
\text { Practices } \\
\text {-Respectful Treatment } \\
\text { of Employees }\end{array}$ & 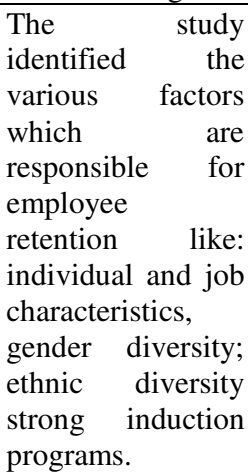 \\
\hline $\begin{array}{l}\text { Prof. } \\
\text { Priyadarshni } \\
\text { Nidan }{ }^{[85]} \\
\text { (2016) }\end{array}$ & $\begin{array}{l}\text { To measure the } \\
\text { employee } \\
\text { engagement in retail } \\
\text { Indian sector. }\end{array}$ & $\begin{array}{lr}50 \text { semi structured } \\
\text { questions } & \text { are } \\
\text { prepared which } & \text { wuestions } \\
\text { contain } & \text { quation } \\
\text { related to motivation } \\
\text { and pride and } \\
\text { performance and } \\
\text { commitment. } \\
\text { Primary data is } \\
\text { collected from the } \\
\text { managerial level } \\
\text { employees of } 5 \\
\text { different retail } \\
\text { store.( Indian Retail } \\
\text { Sector) }\end{array}$ & $\begin{array}{l}\text {-Motivation } \\
\text {-Enthusiasm and } \\
\text { willingness to work } \\
\begin{array}{l}\text { Performance } \\
\text { commitment - and }\end{array}\end{array}$ & $\begin{array}{l}\text { There are several } \\
\text { factors like } \\
\text { commitment, } \\
\text { Dedication, } \\
\text { compensation } \\
\text { which influence } \\
\text { the employee } \\
\text { performance and } \\
\text { motivation in the } \\
\text { organization. }\end{array}$ \\
\hline
\end{tabular}




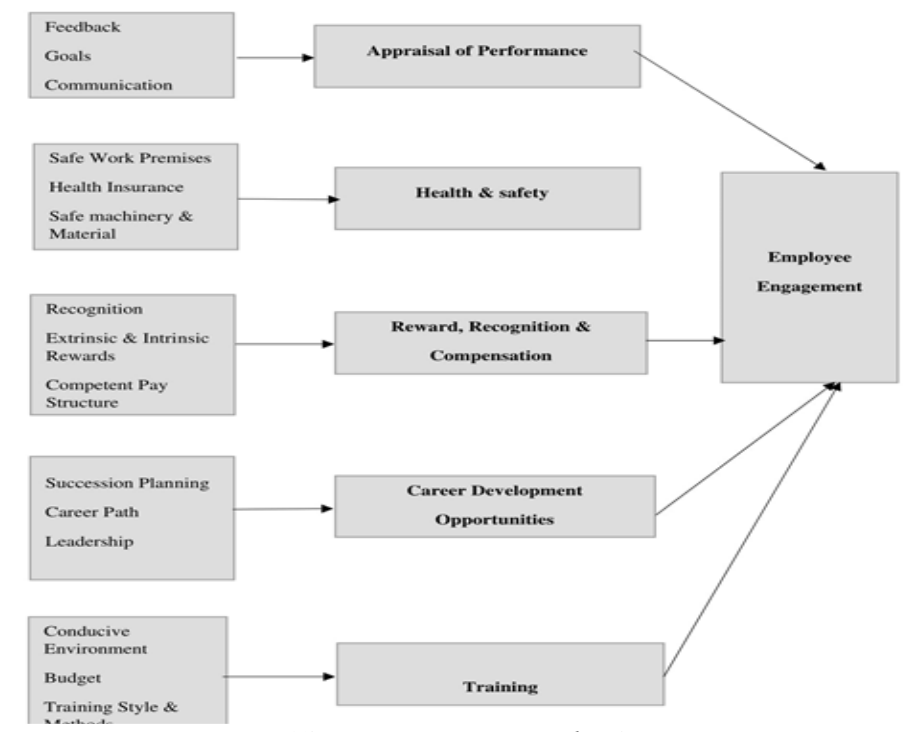

(Source: By Researcher)

Figure 1. Conceptual Employee Engagement \& Retention Model

\section{RECOMMENDATIONS}

The studies in this study revealed that in $21^{\text {st }}$ century it has been a very crucial and difficult task to manage and retain the employees. So the management need to know and understand the perception and mobility of employees dynamically because preference can change rapidly. So proper attention has to be made to reduce employee turnover rates by applying new and competent retention strategies all the time. As said by Cappelliit's not about managing a dam but to manage the entire river. So the HR professionals must have a concise vision and mission with a continuous flow of strategies and people thought so that knowledge is being transferred have to assess the need of employees.

\section{SUgGeSTIONS}

After the analysis of various studies on employee retention\& engagement some points might be consider for retention \& engagement of employees as under:

- Actively promote organizational effectiveness, reputation and values \& ethics

- Clear paths to advancements

- Ongoing Training \& Education

- Offer the Rights Benefits

\section{Conclusion}

With the integration of key employee engagement \& retention along with the psychological state wellbeing may facilitate a very useful tool for achieving and improving organizations success. 
The existing studies shows the different aspects of employee engagement and retention. After analyzing various research papers a definition of engaged and retained employee came out that an engaged employee is one who is motivated, highly dedicated, ambitious, strive to for an extra edge and always lead by the example to others and align his goals toward organizational goals. The studies concerned with employee engagement revels that factors like level of employee engagement in highly correlated the nature of job, communication ease, leadership styles, and trust level and job autonomy, level of motivation, work involvement, support from organization, performance appraisal, quality of work life, level of involvement in decision making, opportunity to grow are the strongest drivers of employee's engagement. The various studies on employee retention postulated some aspects of it mainly includes level of training \& development facilities, culture of organization, leadership quality, feedbacks, compensation structures determines the tenure of the talented employees certainly affects the tenure of employees with dedication.In this era of tough competition it is on the card for the HR professionals to apply a mix and match of employee retention \& engagement strategies to engage and retain talented workforce for longer period of time. For the future concern an Additional theory/practical approach has to be required to analyse and determines the various employee retain and engagementstrategies. The HRstrategies\&practices analyzed in the study suggested and recommended for better competitiveedge for the organizations.This study will restoring and pilot further future research and establish the significance HRM of practices and align them strategically for employee engagement \& retention.

\section{REFERENCES}

[1] Tarique, I., \& Schuler, R. S. (2010) Global talent management: Literature review, integrative framework, and suggestions for further research. Journal of World Business, 45, 122-133. doi:10.1016/j.jwb.2009.09.019.

[2] Chew J., Girardi, A., \& Entrekin, L. (2005) "Retaining core staff: the impact of human resource practices of organization commitment", J. Comparat. Int. Manag.; 8(2):23-42

[3] Hay, M. (2002) Strategies for survival in the war of talent. Career Development International, 7, 52-55. Doi: $10.1108 / 13620430210414883$.

[4] Tims, M., Bakker, A. B., \& Xanthopoulou, D. (2011) Do transformational leaders enhance their followers' daily work engagement? The Leadership Quarterly, 22, 121-131. doi:10.1016/j.leaqua.2010.12.011.

[5] Schaufeli, W. B., Salanova, M., Gonzalez-Roma, V., \& Bakker, A. B. (2002) The measurement of engagement and burnout: A two sample confirmatory factor analytic approach. Journal of Happiness Studies, 3, 71-92.

[6] May, D.R. Gilson, R.L. and Harter, L.M. (2004) The psychological conditions of meaningfulness, safety and availability and the engagement of the human spirit at work. Journal of Occupational and Organizational Psychology.77, 11-37.

[7] Robinson, D. Perryman S. and Hayday, S. (2004) The Drivers of Employee Engagement. Institute for Employment Studies.

[8] Saks, A.M. (2006) Antecedents and consequences of employee engagement. Journal of Managerial Psychology, Vol. 21 No. 7, pp. 600-619. http://dx.doi.org/10.1108/02683940610690169

[9] Maslach, C., Schaufelli, W.B. and Leiter, M.P. (2001) "Job burnout", Annual Review of Psychology, Vol. 52, pp. 397-422.

[10] Shuck, B., \& Wollard, K. (2010) Employee engagement and HRD: A seminal review of the foundations. Human Resource Development Review, 9, 89-110. doi:10.1177/1534484309353560

[11] Khalifeh, A. \& Som. (2013) The Antecedents Affecting Employee Engagement and organizational Performance. Asian Social Science; Vol. 9, No. 7; URL:http://dx.doi.org/10.5539/ass.v9n7p.

[12] Dharmendra, \& Naveen, .K. (2013) Employee Engagement: A Literature Review. Economia, Seria Management, 16(2), 208-215. 
International Journal of BRIC Business Research (IJBBR) Volume 6, Number 1, February 2017

[13] Kwenin, D.O., Muathe, S. \& Nzulwa, R. (2013) The Influence of Employee Rewards, Human Resource Policies and Job Satisfaction on the Retention of Employees in Vodafone Ghana Limited. European Journal of Business and Management, ISSN 2222-1905 (Paper) ISSN 2222-2839 (Online) Vol.5, No.12.

[14] Lieli, S., \& Dendy, S. (2012) The Effects of Organizational Culture and Leadership Style toward Employee Engagement and Their Impacts toward Employee Loyalty.

[15] Kumar, P., \&, Shweta, G. (2011) A Prognostic Examination of Employee Engagement from its Historical roots. International Journal of Trade, Economics and Finance, Vol2 No3, 232-241.

[16] Schaufeli, W. B. and Bakker, A. B. (2004) Job demands, job resources, and their relationship with burnout and engagement: a multi-sample study. Journal Of. Organizational. Behavior. 25: 293-315. doi: 10.1002/job.248

[17] Geetha, J. \& Sebestian, R. (2012) Satisfaction with HR Practices and Employee Engagement: A Social Exchange Perspective. Journal of Economics and Behavioral Studies Vol. 4, No. 7, pp. 423-430s.

[18] Shucka Brad, Reio Thomas G et.al (2011) Employee engagement: an examination of antecedent and outcome variables. Human Resource Development International, Vol 14, No4, 427-445.

[19] Ram, P., \& Gantasala, P. V. (2011) The role of employee engagement in work-related outcomes Interdisciplinary Journal of Research in Business Vol. 1, Issue. 3, (pp.47-61).

[20] Jeung, C. W. (2011) The concept of employee engagement: a comprehensive review from a positive organizational behavior perspective. Performance Improvement Quarterly 24:2, 49-69.

[21] Sarangi, Swatee; Srivastava, R. K. (2012) Impact of Organizational Culture and Communication on Employee Engagement: An Investigation of Indian Private Banks South Asian Journal of Management, 19(3), 18-33.

[22] Ariani, D. W. (2015) Relationship Model of Personality, Communication, Student Engagement, and Learning Satisfaction. Business, Management and Education 13:2, 175-202.

[23] Sundaray, B. K. (2011) Employee Engagement: A Driver of Organizational Effectiveness. European Journal of Business and Management, Vol 3, No.8pp53-59.

[24] Slåtten Terje, MehmetogluMehmet (2011) Antecedents and effects of engaged frontline employees: A study from the hospitality industry Managing Service Quality, Vol. 21Managing Service Quality, Vol. 21 pp88-107.

[25] Karatepe, O. M., \& Nejati, S. K. S. (2010) Do Core Self-Evaluations Mediate the Effect of Coworker Support on Work Engagement? A Study of Hotel Employees in Iran Journal of Hospitality and Tourism Management, $17,62-71$.

[26] Smcey, W.H., Schneider. B. (2008) The meaning of employee engagement. Industrial and organizational psychology, 1, 3-30. Strategy, 23, 32-37. Doi: 10.1108/eb040249

[27] Lockwood .N.R. (2007) Leveraging employee engagement for competitive advantage: HR's strategic role Society for Human Resource Management Quarterly, 1/4.

[28] Lee, Y. K., Kim, S. \&, Kim, S. Y. (2014) The Impact of Internal Branding on Employee Engagement and Outcome Variables in the Hotel Industry. Asia Pacific Journal of Tourism Research 19:12, 1359-1380.

[29] Robertson, I. T., \& Cooper, C. L. (2010) Full engagement: the integration of employee engagement and psychological well-being. Leadership \& Organization Development Journal Vol. 31 No. 4, pp. 324-336. DOI 10.1108/01437731011043348

[30] Rich, B. L., Lepine, J. A., \& Crawford, E. R. (2010) Job engagement: Antecedents and effects on job performance. Academy of Management Journal, 53(3), 617-635.

[31] Schaufeli, W.B. and Bakker, A.B. (2004) "Job demands, job resources, and their relationship with burnout and engagement: a multi-sample study", Journal of Organizational Behavior, Vol. 25, pp. 293-315.

[32] Kumar, A., D. Israel. (2012) Authentic Leadership \& Work Engagement. The Indian Journal of Industrial Relations, Vol. 47, No. 3, pp. 498-510.

[33] Chaminade, B. (2007) A Retention Checklist: How Do You Rate? Retrieved on 11th March, 2012,from www.humanresourcesmagazine.co.au

[34] Samuel, M. O. (2008) Using Motivational Strategy as Panacea for Employee Retention and Turnover in Selected Public and Private Sector Organizations in Eastern Cape Province of South Africa. Unpublished M.Sc. Thesis, University of Fort Hare.

[35] Chiboiwa, M. W., Samuel, M. O., \& Chipunza, C. (2010) An Examination of Employee RetentionStrategy in a Private organization in Zimbabwe. African Journal of Business Management,4(10), 2103-2109.

[36] Frank, F. D., Finnegan, R. P. and Taylor, C. R. (2004) The Race for Talent: Retaining and Engaging Workers in the 21st Century. Human Resource Planning, 27(3), pp. 12-25.

[37] Ejiofor, P. N. O., \&, Mbachu, A. U. (2001) Imperative of Human Resource Practices in the NewMillennium. Journal of the Management Sciences, 5(1), pp. 121-126. 
International Journal of BRIC Business Research (IJBBR) Volume 6, Number 1, February 2017

[38] Nwokocha, I., \& Iherirohanma, B. J. E. (2012) Emerging Trends in Employee Retention Strategiesin a Globalizing Economy: Nigeria in Focus. Asian Social Science, 8(10), pp. 198-207.

[39] Ongori, H. (2007) A review of the literature on employee turnover. African Journal of Business Management, 1(3), 49-54.

[40] Montgomery, J.D. (2006) The relationship between training and retention in a volunteer organization. PhD Dissertation, Auburn, Alabama: Auburn University. pp. 72-77.

[41] Paul, A.K., Anantharaman, R.N. (2003) Impact of people management practices on organizational performance: analysis of a causal model. International Journal of Human Resource Management, 14(7), 1246-1266.

[42] Barringer, B.R., Jones, F.F., Neubaum, D.O. (2005) A quantitative content analysis of the characteristics of rapid-growth firms and their founders. Journal of Business Venturing, 20, 663-687.

[43] Miller, D. (2006), Strategic human resource management in department stores: an historical perspective. Journal of Retailing and Consumer Service, 13(2), 99-109.

[44] Roberts, J.A., Coulson, K.R., Chonko, L.B. (1999) Salesperson perceptions of equity and justice and their impact on organizational commitment and intent to turnover. Journal of Marketing Theory and Practice, 7, 1-15.

[45] Zingheim, P.K., Schuster, J.R., Dertien, M.G. (2009) Compensation, reward and retention practices in fastgrowth companies. World at Work Journal, 18(2), 22-39.

[46] Chew, J., Chan, C.C. (2008) Human resource practices, organizational commitment and intention to stay. International Journal of Manpower, 29(6), 503-522.

[47] Schein, E. (1990) Organizational culture. American Psychologist, 45(2), 109-119.

[48] Vlachos, I.P. (2009) The effects of human resource practices on firm growth. International Journal of Business Science and Applied Management, 4(2), 17-34.

[49] Elicker, J. D., Levy, P. E., \& Hall, R. J. (2006) The role of leader-member exchange in the performance appraisal process. Journal of Management, 32, 531-551.

[50] Schaufeli, W. B., \& Salanova, M. (2008) Enhancing work engagement through the management of human resources. In K. Näswall, J. Hellgren, \& M. Sverke (Eds.).The individual in the changing working life (pp. 380-402). New York: Cambridge University Press.

[51] Zhu, W., Avolio, B. J., \& Walumbwa, F. O. (2009) Moderating role of follower characteristics with transformational leadership and follower work engagement. Group and Organization Management, 34, 590-619.

[52] Kahn, W.A. (1992) “To be full there: psychological presence at work”, Human Relations, Vol. 45, pp. 321-49.

[53] Schaufeli, W., \& Salanova, M. (2007) Work engagement: An emerging psychological concept and its implications for organizations. In S. W. Gilliland, D. D. Steiner, \& D. P. Skarlicki (Eds.), Managing social and ethical issues in organizations (pp. 135-177). Greenwich, CT: Information Age Publishing.

[54] Xanthopoulou, D., Bakker, A. B., Demerouti, E., \& Schaufeli, W. B. (2009). Work engagement and financial returns: A diary study on the role of job and personal resources. Journal of Occupational and Organizational Psychology, 82, 183-200.

[55] Atwater, L. E., Brett, J. F., \& Cherise-Charles, A. (2007) Multisource feedback: Lessons learned and implications for practice. Human Resource Management, 46, 285-307.

[56] Jeswani, S., \& Sarkar, S. (2008) Integrating Talent Engagement as a Strategy to High Performance and Retention. Asia-Pacific Business Review, Vol. IV, No. 4, pp. 14-23. https://www.researchgate.net/publication/258122394

[57] Ologbo C. Andrewa, O.C., \& Sofianb, S. (2012) Individual Factors and Work Outcomes of Employee Engagement. Social and Behavioral Sciences Elsevier, 40, 498 - 508. www.sciencedirect.com

[58] Hanif, M.I., \& Yunfei, S. (2013) The role of talent management and HR generic strategies for talent retention. African Journal of Business Management, Vol.7 (29), pp. 2827-2835, 7.

[59] Kwenin, D.O., Muathe, S. \& Nzulwa, R. (2013) The Influence of Employee Rewards, Human Resource Policies and Job Satisfaction on the Retention of Employees in Vodafone Ghana Limited. European Journal of Business and Management, ISSN 2222-1905 (Paper) ISSN 2222-2839 (Online) Vol.5, No.12.

[60] Appiah, F.A., Kontor, E., \& Asamoah, D. (2013) Effect of human resource management practices on employee retention: perspectives from the mining industry in Ghana. International Research Journal of Arts and Social Sciences, (Vol. 2(2) pp. 30-48.

[61] Ariani, D.W. (2013) The Relationship between Employee Engagement Organizational Citizenship Behavior and Counterproductive Work Behavior. International Journal of Business Administration, Vol. 4, No. 2. URL:http://dx.doi.org/10.5430/ijba.v4n2p46 
International Journal of BRIC Business Research (IJBBR) Volume 6, Number 1, February 2017

[62] Simbula, S., Gujlielmi, D. (2013) I am engaged, I feel good, and I go the extra-mile: Reciprocal relationships between work engagement and consequences. Journal of Work and Organizational Psychology, Vol-29, issue-2, pp. 117-125.

[63] Habib, S., Aslam, S., Hussain, A., Yasmeen, S., \& Ibrahim, M. (2014) The Impact of Organizational Culture on Job Satisfaction, Employees Commitment and Turn over Intention. Advances in Economics and Business, Vol.2 (6): 215-222. DOI: 10.13189/aeb.2014.020601

[64] Tangthong, Sorasak. (2014) The effects of Human Resource Management Practices on Employee Retention in Thailand's Multinational Corporations. International Journal of Economics, Commerce and Management Vol. II, Issue 10, ISSN 2348- 0386.

[65] Geldenhuys, M., Laba, K., \& Venter, C.M. (2014) Meaningful work, work engagement and organizational commitment. SA Journal of Industrial Psychology, 40(1), Art. 1098, 10 pages. http:// dx.doi.org/10.4102/sajip. v40i1.1098.

[66] Raytona, B.A., \& Yalabika, Z.Y. (2014) Work engagement, psychological contract breach and job satisfaction. The International Journal of Human Resource Management, 5192.2013.876440. http://dx.doi.org/10.1080/09585192.2013.876440

[67] Muhoho, J.M.E. (2014) Assessment of factors influencing employee retention in Tanzania's work organizations. International Journal of Innovation and Applied Studies, ISSN 2028-9324 Vol. 9 No. 2, pp. 687697.

[68] Isa, A., \& Ibrahim, H.I. (2014) Talent Management Practices and employees engagement: A study in Malaysian GLCs. International Journal of Business, Economics and Law, Vol. 4, Issue 1 (June) ISSN 2289-1552.

[69] Bedarkar, M., \& Pandita, D. (2014) A study on the drivers of employee engagement impacting employee performance. Procedia - Social and Behavioral Sciences, Elsevier Ltd., 133, 106 - 115.

[70] Breevaart, K., Bakker, A.B., \& Demerouti, E. (2014) Daily self-management and employee work engagement. Journal of Vocational Behavior, No. 84, 31-38. www.elsevier.com/locate/jvb

[71] Kaliannana, .M, \& Adjovu, S.N. (2015) Effective employee engagement and organizational success: a case Study. Procedia - Social and Behavioral Sciences, 172, pp. 161-168. Available online at www.sciencedirect.com.

[72] Haider, M., Rasli, \& A., Akhtar, C.B. (2015) The Impact of Human Resource Practices on Employee Retention in the Telecom Sector. International Journal of Economics and Financial Issues, 5(Special Issue) 63-69.

[73] Jago, M.DL. (2015) Revisiting talent management, work-life balance and retention strategies. International Journal of Contemporary Hospitality Management, Vol. 27 No. 3, pp. 453-472. DOI 10.1108/IJCHM-12-20130538

[74] Bhattcharya, Y. (2015) Employee Engagement as a Predictor of Seafarer Retention. The Asian journal of shipping \& logistics, Volume 31 Number 2, pp. 295-318.

[75] Imna, M. \& Hassan, Z. (2015) Influence of Human Resource Management practices on Employee Retention in Maldives Retail Industry. International journal of Accounting, Business \& Management, ISSN 2289-4519, Vol.1, http://www.ftms.edu.my/journals/index/php/journals/ijabm.

[76] Albrecht, S.L., Bakker, A.B., Gruman, J.A., Macey, W.H., \& Saks, A.M. (2015) Employee engagement, human resource management practices and competitive advantage: An integrated approach. People and Performance, Vol. 2 No. 1, pp. 7-35, ISBN: 2051-6614. http://dx.doi.org/10.1108/JOEPP-08-2014-0042

[77] Oliveira, L.B.D., \& Silva, F.F.R.A. (2015) The Effects of High Performance Work Systems and LeaderMember Exchange Quality on Employee Engagement: Evidence from a Brazilian Non-Profit Organization. Procedia Computer Science, Elsevier 55 (2015) 1023 - 1030. www.sciencedirect.com

[78] Saul, M.C., Kim, W., \& Kim, T. (2015) Leadership and Employee Engagement: Proposing Research Agendas through a Review of Literature. Human Resource Development Review, Vol. 14(1) 38- 63. DOI: $10.1177 / 1534484314560406$

[79] Rashid, S., \& Harif, M.A.A.B.M. (2015) Employee Engagement: A Qualitative Research on Critical factors with in Malaysia's SME business. First Asia Pacific Conference on Contemporary Research, (APCCR- ISBN: 9780994365699.

[80] Alshammari, H. (2015) Workplace Productivity through Employee Workforce Engagement: A Review Study. International Journal of Business and Social Science, Vol. 6, No. 12, pp. - 156-162.

[81] Hong, E.N.C., Hao, L. Z., Kumar, R., Ramendran, C., \& Kadiresan, V. (2016) An Effectiveness of Human Resource Management Practices on Employee Retention in Institute of Higher learning: - A Regression Analysis. International Journal of Business Research and Management (IJBRM), Volume (3): Issue (2): 60- 79. 
International Journal of BRIC Business Research (IJBBR) Volume 6, Number 1, February 2017

[82] Pittino, D., Visintinb, F., Lenger, T., \& Sternad, D. (2016) Are high performance work practices really necessary in family SMEs? An analysis of the impact on employee retention. Journal of Family Business Strategy, 7 (2016) 75-89. www.e lsevier.com/locate/jbs

[83] Kumudha, A., Harsha KJ. (2016) The relationship between human resource practices and employee retention in private organizations with special reference to Jebel Ali international hospital in Dubai. International Journal of Applied Research, 2(5): 961-966. ISSN Print: 2394-7500.

[84] Chandani, A., Mehta, M., Mall, A. \& Khokhar, V. (2016) Employee Engagement: A Review Paper on Factors Affecting Employee Engagement. Indian Journal of Science and Technology, ISSN (Print): 0974-6846. DOI: 10.17485/ijst/2016/v9i15/92145

[85] PriyadarshniNidan, P. (2016) Study the impact of employee engagement on employee productivity and motivational level of employee in retail sector. IOSR Journal of Business and Management, (IOSR-JBM) eISSN: 2278-487X, p-ISSN: 2319-7668 PP 41-47.

\section{Authors}

\section{Munish}

Munish is presently working as an assistant professor at Aravali College of Engineering \& Management, Faridabad. The author has 8 years of teaching experience in various Management discipline subjects. The author is presently Pursuing PhD from YMCA University of science \& Technology, Faridabad.

\section{Dr. Rachna Agarwal}

Dr. Rachna Agarwal is presently working as an associate professor in YMCAUST, Faridabad. He has a teaching experience of more than 13 years. She has actively involved in research area and having more than 15 research papers in national and international

journals and contributed in many conferences as well.

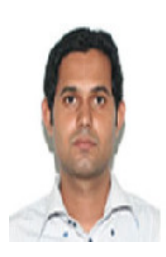

(1)

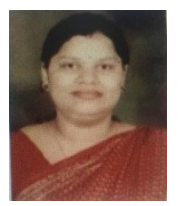

